\section{荋王五色岳の二重火口}

\section{田辺健一}

蔵王火山の刈田岳から能野岳にわたる馬ノ背 カルデラの北東底に, 中央火口丘の五色岳があ り，火口湖お釜がある。

五色岳は熔岩の噴出のないホマーテとして知 られ，お釜は強酸性湖として有名である。

お釜火口の東側に, ほょ同形, 同大の, 円形 の踓みがあり，北と東側が高く，南側が低く， 一部が切れて窪地の排水が行なわれている。

この窪地は, 形態的には, お釜より古い火口 である, と以前から考えていたが，ようやくそ の証拠を観察することがでさた。1968 年10月 26日, 熊野岳から馬ノ背で, スケッチの如き観 察がそれである。

すなわち，お釜火口壁東部の断面に，他の部 分と異る, 火山噴出物累層の乱れがある。東部 涳地の円形山稜の延長部分と見えるところで層 の高まりがあり，北の高まりでは，扣釜北壁の 層が何の乱れもなく南の高まりの方へ続いてい、 る。2つの高まりを結ふゆるい弧状の風以下は その上部と色拈よび形で明瞭に区別できる。し かも,この南と北との高まりの外側では，外へ 向って傾斜していて, 臼状火山の模型断面を見 るが如くになっている。
以上のことから，お釜火口の東部の窪みはお 金より古い火口と断定することができる。

なお，さらに東に接し，小さいが，かなり緩 傾斜な部分があり，より古い火口の一部ではな いかとの疑問が残る。

従って, 蔵王山頂部の地形学図は次のように なる。

(1969. 1. 13 受理)
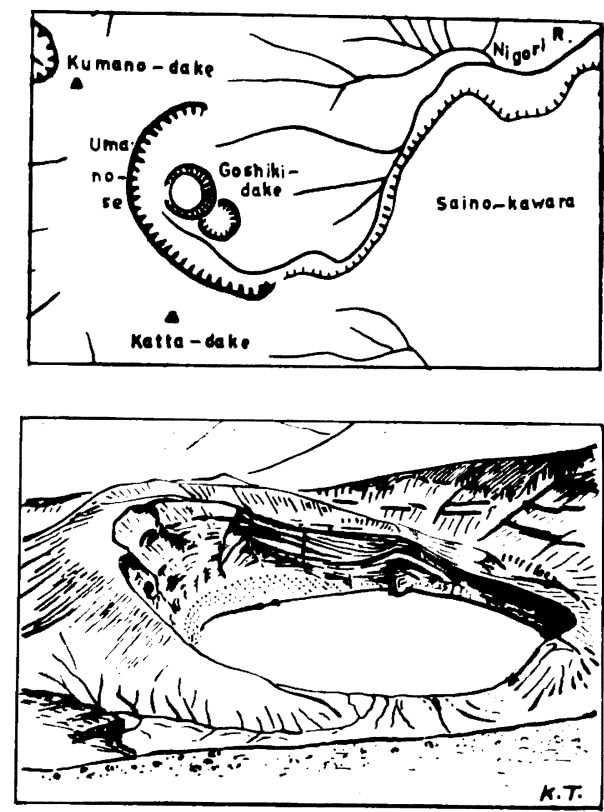

\title{
Double Graters of Goshiki-dake Homate at Mt. Zao
}

\section{Ken-ichi TANaBE}

\begin{abstract}
"Okama" is a crater lake at Mt. Goshiki-dake $(1,674 \mathrm{~m})$, which is a central cone in the Uma-no-se caldera, at the top of Mt. Zao, Miyagi Prefecture.

There is a shallow depression in contact with the east side of the Okama crater. A disturbance of the alternation of volcanic ash and sand is seen on the eastern wall of its crater as is shown in the sketch.

Thus it is confirmed that the depression is an older crater.
\end{abstract}

